\title{
Uncertainty and Method
}

\section{Whiteness, Gender and Psychoanalysis in Germany}

\author{
Martina Tißberger
}

FREE UNIVERSITY BERLIN

ABSTRACT This article discusses the methodological challenges posed for psychological research on whiteness at the intersection between race and gender in Germany. Much of the current research in the social science field in Germany focuses on violent expressions of racism or Fremdenfeindlichkeit (hostility towards strangers) and represents a collective immunization against the knowledge about the history and the historicity of whiteness as a history of seizure. Such approaches are motivated by fear and uncertainty. The author takes this uncertainty not only as a starting point for an investigation into the heavily veiled history of whiteness, but also as a method in itself.

KEY WORDS feminist epistemologies $\bullet$ gender $\bullet$ Germany $\bullet$ psychoanalysis racism $\bullet$ whiteness

Whiteness as a social construction within the system of 'race' has been the subject of research in many English-speaking academic fields. It has been investigated as a neutral standpoint from which the 'Other' is defined, although the definition of 'whiteness' itself remains uncertain (Frankenberg, 1997), existing either as an absent centre (Pajaczkowska and Young, 1992) or as a master signifier (Seshadri-Crooks, 2000). Yet whiteness as a subject matter is a new concept in Germany and evokes a number of issues, leading back to both the Nazi racial ideology of 'race' as well as the denial of Germany's colonial history in public discourse. While there is plenty of research conducted on the racism of right-wing extremists, research on whiteness in Germany, however, triggers defensiveness and fear. White researchers remain in a safe position so long as they approach racism from the standpoint that it has little relevance with their own position.

White people can easily deny they are racist, but even for them it would be fundamentally flawed to deny they are white. If one accepts the

European Journal of Women's Studies Copyright (C) 2005 SAGE Publications (London, Thousand Oaks and New Delhi), 1350-5068 Vol. 12(3): 315-328; DOI: $10.1177 / 1350506805054272$ 
existence of racism and the social injustices that flow from it, then one also has to acknowledge that somebody profits from these injustices. The racist system benefits white people at large but most perceive these privileges as simply a normal state of affairs. From this 'white standpoint', most people then assume that Black ${ }^{1}$ people's social failures are merely a result of individual incompetence rather than a consequence of structural discrimination. The dominant conception of racism in Germany hence covers only obvert and blatant racism whereas more subtle or subvert forms are rarely recognized as racism. As is further extrapolated in this article, such a definition leads to a collective immunization against the knowledge that the history of whiteness is really about the history of seizure. Accordingly, research on racism, which focuses on whiteness rather than on the neoNazis who exercise violent racism, opens up uncertainty, fear and defensiveness within the white community.

Classifying whiteness as a marking point in racist systems does not allow for the possibility of exceptions. Whiteness becomes a fixed position, less mutable than other variables such as class, economic status, sexual orientation or political positioning. If a researcher comprehends the true meaning of whiteness, she/he is forced to acknowledge that she/he is equally involved in the system of 'race'. Moreover, identifying oneself as an anti-racist no longer has any meaningful significance. The fear that stems from the realization that whiteness is a signifier of seizure leads to a methodological dilemma. Indeed, this is the subject matter of this article. I examine the methodological challenges created in the process of mapping the blank ${ }^{2}$ or 'white' spot in the history of seizing and legitimizing rule. That is, I consider how constructions of whiteness can be discovered in the narratives of white speakers who wish to see themselves as non-racial in order to remain outside the play of signification even as they enable the system of 'race', in the words of Kalpana SeshadriCrooks (2002: 20).

How can a dethematized issue, stored in the unconscious, be effectively investigated? Which method enables us to advance this research despite the political and perhaps psychological opposition on the part of scientists and scholars active in the critique of racism? The social scientists who develop methods for qualitative empirical research in western academia are likely to be white. As such, they are not interested in understanding the meaning of their own whiteness within the system of 'race' and in their research on racism. Agreeing with Georges Devereux, I suspect that their methods run the risk of functioning as a protection barrier for white people (including myself) against the subject matter - whiteness - rather than increasing our knowledge about racism.

In this article I would like to demonstrate how the power-imbalanced colonial relationship of white Self and racialized Other links with the gendered relationship between 'the' male (white) Self and 'his' female 
(white) Other. In other words, I explore how gender is racialized and how 'race' is gendered. Processes of gendered and racial othering veil and blur the seizures that accompany their history, which is the history/icity of whiteness. I then briefly discuss several psychoanalytic studies on whiteness, that suggest that the history of whiteness as a history of seizure has become embedded in the (white) psyche. Through reflections on epistemology and the example of a methodology workshop that I used for the empirical part of my psychological research on whiteness and feminism, I finally attempt to demonstrate how uncertainty can act as a valid starting point for an enquiry into a heavily veiled history.

\section{SUBJECT OBJECT ABJECT: HISTORICAL AMNESIA AND MEMORY WORK}

A key concept of psychoanalytic theory when applied to the issue of racism is the projection of 'split-off' parts of the white/European Self onto the 'Other', which is thereby racialized. As I discuss further in this article, the reception in Germany of psychoanalytic approaches to racism has thus far worked with the concept of projection of split-off parts but fails to thematize the correlation of this projection with the seizure over the racialized subject. As such, this research runs the risk of individualizing and psychologizing racism, and, in essence, it suggests that racism is a deviation rather than the normality in a white-dominated culture such as Germany. In an article on racism, representation and psychoanalysis, Claire Pajaczkowska and Lola Young (1992) use psychoanalytic theory to deconstruct racism in cultural productions such as film and literature. Speaking from a postcolonial British context, they describe the European history of seizure and expansion (i.e. a history of racism and sexism) as a type of denial of human interdependency. The dependence of the wealth of the rich on the poverty of the poor, the progress of the so-called 'First World' in helping the backwardness of the 'developing countries', the dependency of alleged rational masculinity on emotional femininity are described as parasitic and a history of seizure, which needs to be veiled and repressed. The authors thereby contextualize the psychodynamic of racism and investigate it from a social and individual perspective rather than individualizing or psychologizing racism. 'Race' and racism have a history and any analysis of 'race' and racializing processes needs to be historicized.

Toni Morrison (1993) argues for a historization of 'race' in her book Playing in the Dark and talks about the parasitical nature of white freedom. She argues that, 'we should not be surprised that the Enlightenment could accommodate slavery; we should be surprised if it had not. The concept of freedom did not emerge in a vacuum. Nothing highlighted freedom - if 
it did not in fact create it - like slavery' (Morrison, 1993: 38). Her critique of white US-American literature reveals how constructions of the white enlightened subject as free are heavily dependent on the creation of racial difference: for in that construction of blackness and enslavement could be found not only the not-free but also, with the dramatic polarity created by skin colour, the projection of the not-me (Morrison, 1993: 38).

According to Pajaczkowska and Young, the absence of whiteness in the European historiography caused by the denial of imperialism has resulted in a blank spot in recollections of the destructive effects of seizure. The authors draw the line between experiences of infantile loss of omnipotence and the absence of the identity of white culture - an absent centre. They argue that early experiences of a loss of infantile omnipotence and a realization of dependence upon the nursing mother eventually develop into an adult narcissism, which functions as a defence against feelings of helplessness and a traumatic loss of self-respect. Because the infantile experience is repressed it will exist as an unconscious memory of threat, and it is the intensity of the pressure exerted by this memory that lies beneath the blankness identified as the absent centre of white identity (Pajaczkowska and Young, 1992: 203). According to Pajaczkowska and Young, within European history descriptions of whiteness are absent due to denial of imperialism, and this leaves a blank in the place of knowledge of the destructive effects of wielding power (Pajaczkowska and Young, 1992: 202).

However, Jean Walton (1997) argues that the very coming into being of psychoanalysis depended upon particular notions of 'race'. On the interrelation of 'race', psychoanalysis and feminism, she notes that:
. . . white Americans in a country with a history of a racialized slavery system, of racialized lynching practices, of racialized divisions of labour, indeed, of a racialized history of child care, where the tasks of the mother so typically described in psychoanalytic accounts of early development (nursing, cleaning, eroticising certain zones of the body, assisting in the acquisition of language, mediating in the mirror stage) were (and continue to be) undertaken by black women in the white slave-owning or servant- employing household. It could be argued that it is just as much the case for Europeans, whose fantasmatic life is permeated by the Orientalist and Africanist ideologies that underwrite and justify what, by the time psycho- analysis was in its nascent stages, had become a long and vexed history of European colonialist expansion and decline. (Walton, 1997: 225-6)

Anne McClintock (1995) argues that, 'the disciplinary quarantine of psychoanalysis from history was germane to imperial modernity itself ... . for it was precisely during the era of high imperialism that the disciplines of psychoanalysis and social history diverged'. She therefore calls for a 'renewed and transformed investigation into the disavowed relations between psychoanalysis and socioeconomic history' (McClintock, 1995: 8). 
Following the example of Julia Kristeva, McClintock then examines through psychoanalytic subject theory, abjection as constitutive of the Self and, I want to add, the 'civilized' Self. According to Kristeva, a subject or a social being is constituted through exclusion. In order to become social, the Self has to expunge the elements that society declares impure and dirty, such as excrements, menstrual blood, urine, semen, tears, masturbation or incest. Kristeva calls this process 'abjection' (McClintock, 1995: 71). However, these expelled elements, as McClintock explains, can never be fully obliterated; they haunt the edges of the subject's identity with the threat of disruption or even dissolution. McClintock continues:

The abject is everything that the subject seeks to expunge in order to become social; it is also a symptom of the failure of this ambition. As a compromise between condemnation and yearning, abjection marks the borders of the self; at the same time, it threatens the self with perpetual danger. . . . the expelled abject haunts the subject as its inner constitutive boundary: that which is repudiated forms the self's internal limit. The abject is something rejected from which one does not part. (McClintock, 1995: 71)

This argument lends credence to the views of Kalpana Seshadri-Crooks. In her Lacanian analysis of 'race' she suggests - and I have mentioned this point earlier - that whiteness is the master signifier of 'race' (not Blackness) and that it relies on a regime of visibility. She sees racial visibility as related to an unconscious anxiety about the historicity of whiteness (Seshadri-Crooks, 2000: 21). Whiteness, as she argues further, attempts to signify wholeness, being and jouissance - enjoyment. Assembling together the theoretical arguments that I have borrowed from Pajaczkowska and Young, McClintock and Seshadri-Crooks allows me to form a provisional thesis. Encounters between white and non-white people trigger anxieties within the former and these anxieties lead back to the historicity of whiteness. Racially othered subjects 'remind' white subjects that they are not autonomous, whole and independent but rather reliant on this 'Other' who has become the field of projection for the abjected parts of the white Self. This 'Other' has become abject in order for the white Self to remain a subject - or a construction of a subject. This abjection marks the borders of the white Self and is characterized by an ambivalence of condemnation and yearning - that is, xenophobia and exoticism. The expelled abject haunts the subject as its inner constitutive boundary (McClintock, 1995: 71) and this produces anxiety and uncertainty.

I argue that working with the psychoanalytic instruments of transference and countertransference enables us to investigate the historicity of whiteness and that its reinscription into the white subject's consciousness could potentially interrupt this history. This his/story might be one, that - in the words of postcolonial critic Trinh T. Minh-ha: 
... never really begins nor ends, even though there is a beginning and an end to every story, just as there is a beginning and an end to every teller. One can date it back to the immemorial days when a group of mighty men attributed to itself a central, dominating position vis-à-vis other groups; overvalued its particularities and achievements; adopted a projective attitude toward those it classified among the out-groups; and wrapped itself up in its own thinking, interpreting the out-group through the in-group mode of reasoning while claiming to speak the minds of both the in-group and the out-group. (Trinh T. Minh-ha, 1989: 1)

To reinscribe whiteness into European history within the scope of empirical research through the use of the psychoanalytic concepts of transference and countertransference can be advantageous. It enables researchers to interrogate their preconscious knowledge about the colonial histories and their role as whites within it. However, the potentially racist, neocolonial unconscious of the white, 'First World' researcher can be denied, ignored, or reflexively explored. The researcher can choose either to rest comfortably in the pseudo-certainties of white privilege or venture into uncertainty.

\section{IN THEORY: WHITENESS, FEAR AND METHOD}

A founding figure of ethno-psychoanalysis is Georges Devereux, who in 1967 published a book with the remarkable title From Anxiety to Method in the Behavioral Sciences. The core thesis of this book is that researchers produce many countertransferences of their anxieties in the process of investigating socially 'tabooed' issues. Interestingly, in Germany, where a decent field of psychoanalytic research on 'ethnological' subject matters as well as on racism has been developed, Devereux acts as an important point of reference while his ground-breaking remarks about methodologies serving as defence against the anxiety of the researcher have, to a large degree, been neglected when it comes to the white subject and her/his anxiety around 'race'.

Whereas much research in Germany explores the relationship between Self and Other/stranger, surveying the meaning of the Other/stranger for the psychological development of the Self (generally assumed to be a white- and often male Self), the history of seizure of that Self over the Other as one of enslaving, colonizing, dehumanizing and exploiting the Other hardly rates a mention. Subject theories by western philosophers that see the relationship between Self and Other as one of equals are taken as the point of departure by which one can draw conclusions about racism in Germany. In this logic, racism is a pathology rather than a white normality.

One strand in the predominantly psychoanalytic discourse on Self and 
Other in Germany focuses on adolescent right-wing extremists and advances the view that racism is a form of deviation. Indeed, almost every case study conducted in this field argues that the racist speech and violence of these right-wing adolescents is a product of interfamilial relationship experiences. Another strand of studies of Self and Other in Germany normalizes racism by claiming that xenophobia - fear of the stranger - is a transcultural, universal phenomenon. Yet none of the authors promoting these theories can adequately explain why only certain subjects are victims of this hostility towards strangers (Fremdenfeindlichkeit).

Hardly any of these scholars seem to register that Afro-Germans, as well as Germans whose great-grandparents migrated from Turkey, are almost always the target of these racist attacks or victims of everyday racisms, whereas white Canadians or white South Africans rarely encounter any such hostility in Germany. The explanation of racism through the application of theories based on power-balanced relations between Self and Other, as debated widely in western philosophy, trivializes the consequences of racial othering. It limits the problem of racism to a minor group of deviants - mainly white lower/working-class adolescents - so as to avoid accepting that the entire dominant white German population continues to carry the colonial images of the inferior 'racial Other' in their minds. Again, I want to suggest that it is the disingenuous 'neutrality' of the white standpoint that sets the norm and thereby immunizes itself from self-questioning.

All too often in the clinical psychological setting, the client who experiences racism is pathologized by a white therapist. Instead of giving support to the client, the white therapist interprets what should be considered an adequate reaction to racism as a developmental disorder or as a neurosis. Psychological method, be it clinical or research, may be used to help the researcher/therapist understand the Other (client or research subject), but it may also be used to protect the researcher/therapist against painful knowledge about him-/herself. It is the anxiety related to the momentum when whiteness becomes historicized. Hence it is often the case that the white therapist, out of fear of realizing her/his own involvement in a racist society, seeks to protect her-/himself and thereby 'blames the victim' of racism. While psychoanalytic training teaches its practitioners to differentiate between a client's transferences and the analyst's countertransferences, an understanding of racism is not included in such training. Although many have criticized psychoanalysis as ignorant about the discrimination of women, racism, with the exception of anti-Semitism and the expressions of neo-Nazis and right-wing extremists, appears not to be a problematic issue for (critical) psychoanalytic discourses in Germany. As a result of the discipline's professional defence against the acceptance of its whiteness as a history of seizure as 
well as its contemporary power in defining racial otherness as deviance, clients who count as Ausländer (racially and/or ethnically marked) in Germany experience enormous difficulties in finding therapists who will not 'other' them over and over again and consequently pathologize in the client what is actually their countertransference of whiteness.

From this admission I recognized the need to research whiteness and the way in which it operates within the psychotherapeutic relationship. In theory I was interested in the history of racism and its inscription into German society and individuals as well as its productions of transferences and countertransferences. I sought to conduct interviews with feminist psychotherapists and have them narrate biographically in order to discover whether racial/ethnic otherness was a theme in their life histories. In addition, I thought it apt to ask direct questions about their work with racially marked clients. In so doing I hoped to collect data that reflected the transferences narrated in the interview. In a former research project that I conducted in Ghana on women's strategies to cope with the Structural Adjustment Programmes forced upon them, I encountered my own racialized and gendered countertransferences vis-à-vis my Ghanaian interlocutors for the first time. The work with transferences as an instrument of enquiry and thereby working with my subjectivity as a researcher rather than aiming for 'objectivity' (which I consider an illusion) seemed adequate for my disciplined enquiry into whiteness. However, I suspected some epistemological problems, because social science empirical methods are usually created by white scientists. The logic of whiteness, namely dethematizing itself, and its historicity as well as its history of seizure while producing a logic of difference as deviance, lack and pathology and constructing and constituting itself as norm and wholeness appeared to be inherent in all of the methods I wanted to apply to my research project. Even though I, as a researcher, was sensitized to transferences related to whiteness, the methodology itself (be it psychoanalytic or another) would not enable an adequate analysis of it.

As I became interested in the relation between whiteness and otherness in the encounters between female psychotherapists and clients with migration biographies in Germany, I was forced to pose a number of questions: how do these therapists handle their images of 'the Jew', the veil, the Balkans, Turks, Blacks, Muslims, Poles and circumcision? How are these images related to their constructions of their own 'identity' as women, feminists, 'interculturally competent', German and white? The latter two were the most challenging aspects. I questioned how I should phrase interview questions on whiteness when it remained such a dethematized issue in Germany, especially when issues relating to German nationality remained problematic for most Germans. Ruth Frankenberg (1993), in her study on the social construction of whiteness with women in the US for example, received elaborate answers on the issue of 
whiteness because her interviewees lived in a society with a discourse on 'race' that included the standpoint of white subjects. In Germany, in contrast, questions of 'race' and whiteness almost automatically trigger defensive reactions.

I sought assistance from experts on qualitative research methods for the interviews and in 2001 participated in an annual methodology workshop sponsored by a centre for qualitative research in Germany. I was fortunate enough to enrol in the workshop of two highly renowned scholars. One was known for his biographic research on Nazi perpetrators, while the other instructor was a psychoanalyst and expert in the psychoanalytic method of in-depth hermeneutic analysis. The psychoanalyst had conducted research and published widely in the area of the social psychology of right-wing extremism. I therefore considered myself to be in good hands with my methodological questions, and handed in my material: an outline of my research project explaining how whiteness was at the centre of my interest as a signifier of 'race' and that I wanted to learn about the relationship of white women/feminists in Germany who work in psychological fields with their clients 'of colour'.

The interview transcript I submitted was a test interview with an acquaintance of mine, which included biographic narrations as well as a dialogical section documenting experiences with 'racial', cultural and other - 'othernesses'. I had hoped that the experts would propose an interview style as well as a method for data analysis within psychoanalytic methodology that could allow me to investigate whiteness. After having tested various styles and methodological approaches, I was hoping that the workshop would enable me to commence the 'actual' research project with the therapists.

\section{CERTAINTY - AUTHORITY: WORKSHOPPING 'RACE' AND GENDER}

The workshop consisted of a large number of passive participants and approximately four active participants, who had, like me, given their materials to the experts for the purposes of discussion. The two experts had already read my interview transcript and research outline. They therefore knew my goals and had prepared an interpretation of the material before the workshop began.

To my surprise the preliminary approach of the psychoanalyst/ workshop instructor was not to look at representations of 'race' or whiteness in my material but to explore the suffering of my interviewee, a white woman. Referring to textual excerpts, he developed an interpretation of the situation, namely that my interviewee, Rose (pseudonym), identified with men and could not find her Self as a woman. While her sister was 
Daddy's beautiful one, as he quoted my interviewee, Rose had the function of replacing a son. Her identification with her mother was unsuccessful and as such Rose suffered from a lack of self-esteem. In addition, she was psychologically abused. According to the workshop leader, the whole issue was culminated in the statement: 'I always felt like I am only worth something when a guy wants to sleep with me.'

At this point, a great deal of the time that had been allocated to discuss my research had passed, and we had not even touched upon the topic of racism. I thus suggested that we studied the part of my material where Rose responds to my question about her experiences of fascination of the 'other' woman, and where she immediately remembers the following story:

Oh yes, this black singer comes to my mind right away and she wanders around in the subculture from bar to bar, singing. And she has this beautiful voice. I've seen her a couple of times ... . always singing songs, collecting money and moving on. And I found her so beautiful, . . . full figured, well, ... what one would think of as female, fertile. Not that anorexic beauty ideal which we actually have. And normally I am not attracted to large women, I am also rather conditioned towards being skinny and anorexic, but this woman fascinated me. Her voice! So I said she has to be in my film. You know, at the time I was doing this film . . . and so I said to my assistant: listen, this woman is flitting around somewhere. Go, try and get her. ... She found her and Pam was willing to be in the film - for nothing! - And she is now practically starting my film, at the very beginning and at the very end.

And I wanted her to - well I wanted her to . . . be like - the angel of the women. Well - I don't know . . basically, the one who is there. I mean, the women don't see her, the four women whom I portray, these four white, middle-class, German women . . . don't see, they do not see this . . . black goddess. It's like this ... who is god? She is black ... that slogan! This godimage. And for me this woman was like a goddess. Or she had this godlike energy. Or ... she ... yes, she fascinated me. And I wanted her to be this ... as the guardian angel of the women ... the anorexic, industrialized women or ... I don't know ... wanted her to continually reappear in the film.

And I didn't manage to get her to attach to me though . . . I, I was also afraid of her! Yeah - and I was glad that Ines [assistant] took care of that because she is at home in this subculture scene, whereas I am rather middleclass socialized and - had this good girl upbringing and was always afraid of people. I just never realized it but . . . but I was in fear of this singer! During the shooting I never managed to bond with her. I hadn't explored her songs really. I was somehow indifferent and detached and I think, and she noticed that. Maybe I exploited her or ... I am often critiqued for objectifying black people.

And Pam doesn't want to participate in the film anymore. Generally she doesn't want to do film anymore. She said that she was in many other films at the time and that she hated film and she doesn't want that anymore. I begged and beseeched her but ... no, I couldn't get through to her anymore.

Since he had not focused on 'race' and whiteness in his preparations for the discussion of my material (despite my unmistakable emphasis in this 
direction), the psychoanalyst was forced to seek an impromptu interpretation of this sequence: here he saw Rose's creative approach to gaining a healthy woman's image through the projection on the black singer. Affirmatively she works herself through her identity problems and tries to develop a positive mother- and woman's image for herself. He continued with this approach for a further five minutes before I interrupted him again, as I realized that even in this scene of the narrative he was still not seeing the 'foreign', the 'Other', the exoticized black singer as having a function beyond that of a vehicle for the alleged identity development of Rose, the Self. I offered him an interpretation of the scene that is not psychoanalytic but rather a cultural studies approach: Pam does not receive any interest as a woman who has a life story to tell, a sad story like the other women in the film. In Rose's 'white' perception (as well as in the workshop instructor's own 'white' perception), Pam can only be imagined as a prop, an objectified subject who assists a story but who cannot narrate herself. Pam's status as a subject is structurally denied. She is perceived by Rose in an exoticizing and racializing way and becomes objectified in her role to serve as a field of projection of white desire and yearning. While the white protagonists, subjected to the male world's ideals of female beauty and suffering from anorexia, fight their ways through the career world, Pam appears to be separate from that world. These (white) beauty ideals do not seem to apply to her. She embodies the archaic, the motherly, the original - the resource and the territory from which the industrialized white world gets its nourishment. A mute guardian angel, she flutters around, the black nanny in the background, always available to pamper the white protagonists, who are in the foreground of the story. She sings them to sleep as they come home from a hard day's work 'out there' in the (white) man's world. She functions as a prop, an object of the filmmaker's imaginary, but is never treated as a real subject. Whatever she might have to express in her songs is of no interest - only her black voice, her black body, are of significance.

The representation is one that approves the occidental, colonizing gaze that situates its wild nature, the stranger, the mystic Other, into the periphery, the border(land), the colony, the so-called 'Third World' as well as into the marginality of migration in a western metropolis in order to celebrate 'civilization', whiteness, the industrialized artificial world, which no matter how complex and complicated, must form the core. Such a view then allows a romanticizing interpretation of Pam's singing jobs as the epitome of independence from the ordinary job market, rather than as a reference to the racist discrimination Pam experiences there. Even though Pam pulled out of the film because she no longer wanted to serve the pushy filmmakers' images of black goddesses, she is still singing in Rose's film - at the beginning and at the end, for Rose has got the shots already. Rose does not want to let go of this beautiful voice. 
Rose was familiar with my research topic and wanted to be part of the research because she was consciously interested in challenging everyday racism, of which we are all part. She also understood that it is necessary to look at white people's images of the racialized Other in order to challenge them. This was the reason why she talked freely about her experiences and fantasies and made no effort to protect herself through the application of politically correct speech. During the interview we discussed the scenes she described and images that she used.

However, the psychoanalyst/workshop instructor dismissed my interpretation of Rose's staging of Pam as moralistic, and compared my argumentation to German Idealism. Relieved to see the instructor - the authority - regaining territory in the situation, a participant took his side. She said that she 'comes from objective hermeneutics' (Ulrich Oevermann) and thought that my working method was not 'clean'. It seemed to her that, instead of letting the material speak to me I was - as in quantitative approaches - simply using the data to prove my hypothesis/ theory. She argued that I should consider the wanderings from bar to bar of the black singer, for example, and deduct from that Rose's clear evidential desire to liberate herself from the sexist norms from which she suffers. A number of participants had apparently become uncomfortable to see the social order in the room shifting. They began to move around nervously in their chairs and after another participant stepped into the dialogue between the instructor and me, and had therefore opened the discussion, others began to join in, arguing for more objectivity and closeness to the text, etc. Even though subjectivity is exactly that which this very psychoanalytic method works with, the psychoanalyst nodded, seeming to welcome his rehabilitation, and added, with no recognition of the irony of his comment, that it was common sense that blacks had beautiful voices.

The interview excerpt is not simply an example of the reproduction of racialized representations. It also exemplifies the very process of the racialization of a subject. Pam could have been one of Rose's protagonists, yet in order to construct whiteness as a signifier for subjectivity, a racial difference needed to be created. Rose therefore actively racialized Pam. The workshop instructor forcefully denied this, and argued that my attempts to regain knowledge of the history of seizure by unveiling acts of racializations are ideological, moralistic and wrong.

\section{CONCLUSION}

The discussions in the workshop over the Pam-Rose interview extract typically represent the dominant pattern of the academic system's reproduction of racist structures: that is, superficially taking on the issue of 
racism, but then subverting the matter. It appears that research on racism in the discipline of psychology is omnipresent in Germany, yet it never seems to leave the centre-periphery structure. ${ }^{3}$

The example of this workshop shows that in Georges Devereux's sense, psychoanalytic method in the realm of research on racism can be used as a defence against knowledge of white complicity with various forms of colonial and neocolonial oppressions '[and against] knowledge of the complex ways in which white racial privilege is constructed so as to benefit whites collectively (e.g., through ideologies of gender, sexuality, and nationality)' (Roman, 1997: 275-6). In the case of (research on) whiteness, anxiety must be the starting point of investigation. The notion of 'race' and racial visibility according to Kalpana Seshadri-Crooks is related to an unconscious anxiety about the historicity of whiteness (SeshadriCrooks, 2000: 21), a historicity which is disavowed. Encounters with the historicity of whiteness trigger a fear of accepting that the signifying totality of whiteness is an illusion. White 'identity' is the illusion of wholeness, of 'Self', autonomy and freedom and the denial of the psychic and any other (e.g. historical, political, economic) interdependence. Such a white 'identity' as the centre is constituted by a raced and gendered Other - outside. Instead of acknowledging this interdependency, whiteness provides those 'inside the system' with (the illusion of) autonomy, freedom and independence. Over the centuries, white communities and discourses have developed multiple mechanisms to maintain this structure. Psychoanalysis operates only through memory, that is remembering, shifting the repressed, the unconscious into (pre)consciousness and through this, working through anxiety and uncertainty. Using uncertainty as a method, the researcher is forced to become comfortable with being uncomfortable.

\section{NOTES}

1. I understand 'race' as a social construction and use lowercase letters for white and black subjects in this text. Using the term 'Black' with a capital letter I refer to Blackness in a political sense. Black would be everybody who experiences racism in Germany.

2. It is customarily called a 'blind' spot but apart from this usage of the term being hostile towards the visually impaired, it would be contradictory in the system of 'race', which is, according to Seshadri-Crooks, a system and even a regime of visibility.

3. Trinh T. Minh-ha $(1989,1991)$ has written elaborately about the ways in which this centre-periphery structure is constantly reconstructed by western sciences. 


\section{REFERENCES}

Devereux, Georges (1967) From Anxiety to Method in the Behavioral Sciences. Paris: Editions Mouton et Co.

Frankenberg, Ruth (1993) White Women, Race Matters: The Social Construction of Whiteness. Minneapolis: University of Minnesota Press.

Frankenberg, Ruth (1997) 'Local Whitenesses, Localizing Whiteness', pp. 1-33 in R. Frankenberg (ed.) Displacing Whiteness, Essays in Social and Cultural Criticism. Durham, NC: Duke University Press.

McClintock, Anne (1995) Imperial Leather: Race, Gender and Sexuality in the Colonial Contest. New York: Routledge.

Morrison, Toni (1993) Playing in the Dark: Whiteness and the Literary Imagination. New York: Vintage.

Pajaczkowska, Claire and Lola Young (1992) 'Racism, Representation, Psychoanalysis', pp. 198-219 in J. Donald and A. Rattansi (eds) 'Race', Culture and Difference. London: Sage.

Roman, Leslie G. (1997) 'Denying (White) Racial Privilege: Redemption Discourses and the Uses of Fantasy', pp. 270-82 in M. Fine, L. Weis, L.C. Powell and L. Mun Wong (eds) Off White: Readings on Race, Power, and Society. New York: Routledge.

Seshadri-Crooks, Kalpana (2000) Desiring Whiteness: A Lacanian Analysis of Race. London: Routledge.

Trinh T. Minh-ha (1989) Woman, Native, Other. Bloomington: Indiana University Press.

Trinh T. Minh-ha (1991) When the Moon Waxes Red. London: Routledge.

Walton, Jean (1997) 'Re-Placing Race in (White) Psychoanalytic Discourse: Founding Narratives of Feminism', pp. 223-51 in E. Abel, B. Christian and H. Moglen (eds) Female Subjects in Black and White. Berkeley: University of California Press.

Marina Tißberger is currently working on her PhD project on constructions of whiteness and racialized as well as ethnical otherness in German feminist discourses under conditions of neocolonial migrations. Since receiving her diploma in 1999, she has taught classes in feminist theory, qualitative methods of feminist research and research on racism at undergraduate and graduate level in the Psychology Department at the Free University of Berlin. Address: Free University Berlin, Department of Educational Sciences and Psychology, Habelschwerdter Allee 45, 14195 Berlin, Germany. [email: mailto:tissberg@zedat.fu-berlin.de] 